\title{
CARDIOVASCULAR DIAGNOSIS IN PATIENTS WITH RHEUMATOID ARTHRITIS, PRIMARY SJÖGREN'S SYNDROME, SYSTEMIC SCLEROSIS AND SYSTEMIC LUPUS ERHYTEMATOSUS
}

\author{
DIJAGNOSTIKA KARDIOVASKULARNIH BOLESTI KOD \\ BOLESNIKA SA REUMATOIDNIM ARTRITISOM, PRIMARNIM \\ SJEGRENOVIM SINDROMOM, SISTEMSKOM SKLEROZOM I \\ SISTEMSKIM ERITEMSKIM LUPUSOM
}

\author{
Vladimir Vasilev ${ }^{1}$, Arsen Ristićl, \\ ${ }^{1}$ Univerzitet u Beogradu, Medicinski fakultet, Beograd, Srbija \\ ${ }^{2}$ Univerzitetski klinički centar Srbije, Klinika za kardiologiju, Beograd, Srbija \\ Correspondence: vladimir.vasilev86@yahoo.com
}

Keywords:

coronary heart disease,

chronic rheumatic diseases,

diagnostics,

cardiovascular risk
Abstract

Cardiovascular diseases (CVD) are the leading cause of death in the world and the most common type of comorbidity in patients with systemic lupus erythematosus (SLE), primary Sjögren's syndrome (SjS), systemic sclerosis (SSc), and rheumatoid arthritis (RA). Chronic inflammation in systemic rheumatic diseases can contribute to the development of CVD. Although risk factors for the CVD in the general population are well known, in patients with chronic rheumatic diseases risk factors for the CVD have not been specified as well as their connection with traditional risk factors, which would explain the increased incidence of CVD in these patients.

Patients with chronic rheumatic diseases (RA, SLE, SjS and SSc) have an increased risk of developing both coronary and carotid atherosclerotic diseases. With the increase of the world's population suffering from rheumatoid autoimmune diseases, and thus increased morbidity and mortality, an adequate diagnostic strategy for the detection of coronary heart disease and risk stratification for their development is necessary. Functional techniques are readily available and can prove the presence of ischemia. In recent years, increasing attention has been paid to anatomical techniques that determine the degree of atherosclerosis. So far, a small number of studies are known that indicate the diagnostic accuracy and importance of functional and anatomical techniques in patients with autoimmune rheumatic diseases. The advantage of anatomical techniques is reflected in the direct visualization of either obstructive or non-obstructive (subclinical) coronary disease, allowing the detection of atherosclerosis in the early subclinical stage. However, information on the hemodynamic consequences of the detected changes remains unknown without functional testing. In asymptomatic patients with autoimmune rheumatic diseases, studies have shown an increased prevalence of silent ischemia and atherosclerosis and thus suggested early screening in the general population. Unfortunately, only a small number of prospective studies that have examined improved prognosis based on screening. Therefore, it is very important to conduct large prospective studies in terms of examining predictive markers of the occurrence and development of coronary heart disease in patients with autoimmune rheumatoid diseases.
Vasilev V. et al. MedPodml 2021, 72(4):1-7 (C)

The authors declare no conflicts of interest. doi:10.5937/mp72-34157

Editorial board: podmladak.med.bg@gmail.com e-ISSN: $2466-5525$ 
Vasilev V. et al. Dijagnostika kardiovaskularnih bolesti kod bolesnika sa reumatoidnim artritisom, primarnim Sjegrenovim sindromom, sistemskom sklerozom i sistemskim eritemskim lupusom. MedPodml 2021, 72(4):1-7

\section{Sažetak}

Kardiovaskularne bolesti (KVB) predstavljaju vodeći uzrok mortaliteta u svetu i najčešći vid komorbiditeta kod bolesnika sa sistemskim eritemskim lupusom (SLE), primarnim Sjegrenovim sindromom (SjS), sistemskom sklerozom (SSc) i reumatoidnim artritisom (RA). Hronična inflamacija u reumatskim bolestima može uticati na ubrzani razvoj KVB. Iako su faktori rizika za razvoj KVB u opštoj populaciji detaljno ispitivani i danas dobro poznati, kod pacijenata sa hroničnim reumatskim bolestima do sada nisu precizirani specifični faktori rizika za razvoj KVB, kao i njihova veza sa tradicionalnim faktorima rizika, čime bi se objasnila povećana incidenca KVB kod ovih bolesnika.

Bolesnici sa hroničnim reumatološkim oboljenjima (RA, SLE, SjS i SSc) imaju povećan rizik za nastanak i koronarne i karotidne aterosklerotične bolesti. Povećanjem brojnosti svetske populacije koja boluje od reumatoidnih autoimunih oboljenja u svetu, a time i povećanim morbiditetom i mortalitetom, neophodna je adekvatna dijagnostička strategija za detekciju koronarne bolesti i stratifikacija rizika za njihov razvoj. Funkcionalne tehnike su lako dostupne i mogu da dokažu prisustvo ishemije. Tokom poslednjih godina sve veća pažnja se poklanja anatomskim tehnikama koje određuju stepen ateroskleroze. Do sada je poznat mali broj studija koji ukazuju na dijagnostičku tačnost i značaj funkcionalnih i anatomskih tehnika kod pacijenata sa autoimunim reumatskim bolestima. Prednost anatomskih tehnika ogleda se u direktnoj vizuelizaciji, opstruktivne ili neopstruktivne (supkliničke) koronarne bolesti, dozvoljavajući detekciju ateroskleroze u ranom supkliničkom stadijumu. Međutim, informacije o hemodinamskim konsekvencama detektovanih promena ostaju i dalje nepoznate bez funkcionalnog

Ključne reči:

koronarna bolest, reumatske bolesti, dijagnostika, kardiovaskularni rizik testiranja. Kod asimtomatskih pacijenata sa autoimunim reumatskim oboljenjima studije su pokazale povišenu prevalenciju neme ishemije i ateroskleroze i time predložile skrining u opštoj populaciji. Na nesreću, postoji mali broj prospektivnih studija koje su se bavile ispitivanjem poboljšane prognoze bazirane na skriningu. Zbog toga je jako bitno da se sprovedu velike prospektivne studije $\mathrm{u}$ smislu ispitivanja prediktivnih markera pojave $\mathrm{i}$ razvoja koronarnih oboljenja kod pacijenata sa autoimunim reumatoidnim oboljenjima.

Uvod

Pacijenti sa inflamatornim reumatskim oboljenjima imaju povećan rizik za razvoj kardiovaskularnih bolesti (1-3). Visok rizik za kardiovaskularnu patologiju kod ovih pacijenata nije samo posledica tradicionalnih kardiovaskularnih faktora rizika (starost, pol, porodična istorija, pušenje, sedentarni način života, holesterol), već i hronične upale i autoimunog odgovora. Značajna uloga inflamacije u razvoju bolesti srca i krvnih sudova je prepoznata relativno skoro (4).

Upala je upravo ključna za vaskularnu disfunkciju kod pacijenata sa autoimunim inflamatornim bolestima. Hronična upala i autoimunost mogu dovesti do ubrzane ateroskleroze. Markeri visoke aktivnosti bolesti ili rezultati ozbiljnosti bolesti povezani su sa povećanim kardiovaskularnim rizikom (5). Autoimuno-inflamatorne reumatske bolesti, kao što su reumatoidni artritis (RA), sistemski eritematozni lupus (SLE), sistemska skleroza (SSc) i Sjegrenov sindrom (engl. Sjögren's syndrome, SjS), povezane su sa ubrzanom aterosklerozom koja dovodi do povećanog kardiovaskularnog rizika. $U$ taj proces su uključene inflamatorne ćelije, hemokini, citokini, proteaze, autoantitela i adhezioni receptori, koji mogu direktno uticati na sve strukture kardiovaskularnog sistema, poput miokarda, srčanih zalistaka, perikarda, provodnog sistema i koronarnih arterija (6).

Kardiovaskularni poremećaji mogu biti blagi i klinički tihi, ali u nekim slučajevima mogu postati ozbiljni i opasni po život. Povećani morbiditet i mortalitet zahtevaju ranu dijagnozu i lečenje.

\section{Reumatoidni artritis}

Reumatoidni artritis (RA) je hronično, multisistemsko, autoimuno oboljenje nepoznate etiologije, čija je glavna klinička manifestacija sinovitis perifernih zglobova (1). Ovo oboljenje je ubikvitarno, nevezano za rasu i znatno je češće kod žena nego kod muškaraca (2 - 3 puta), s tim što se taj odnos sa starenjem smanjuje na 1,2:1 (3). Sa starenjem se povećava učestalost bolesti i najčešće se javlja kod bolesnika uzrasta 35 do 50 godina. Sama bolest obično ima nespecifičan i postepen početak, dok su spontane remisije dosta retke (samo kod 5 - 10\% bolesnika). Ukoliko dođe do destrukcije koštanog tkiva značajno je narušen kvalitet života. Klinički znaci artritisa su: bol, otok i osetljivost i ograničena funkcija zgloba. Najspecifičniji simptom bolesti je jutarnja ukočenost zahvaćenih zglobova koja traje duže od 30 minuta.

Bolest je udružena sa povećanjem opšteg mortaliteta i smanjenjem očekivane dužine života što se, uprkos napretku u lečenju, nije promenilo poslednjih nekoliko decenija (3). Smatra se da je uzrok tome nekontrolisana imunološka-zapaljenjska aktivnost koja određuje stepen agresivnosti bolesti i dovodi do ubrzane ateroskleroze. Posledica toga je prevremeni razvoj KVB, 
Vasilev V. et al. Dijagnostika kardiovaskularnih bolesti kod bolesnika sa reumatoidnim artritisom, primarnim Sjegrenovim sindromom, sistemskom sklerozom i sistemskim eritemskim lupusom. MedPodml 2021, 72(4):1-7

pre svega ishemijske bolesti srca (IBS), koje se danas ističu kao vodeći uzrok mortaliteta kod ovih bolesnika $(1,2)$. Od drugih kardiovaskularnih manifestacija u RA se najčešće javljaju perikarditis, valvularne mane i miokarditis. Čak 35 - 50\% svih smrtnih ishoda ovih bolesnika pripisuje se KVB. Prvi korak u stvaranju aterosklerotičnog plaka je oštećenje endotela koje nastaje pod uticajem različitih faktora, pri čemu poseban značaj imaju ćelije zapaljenja: makrofagi, limfociti, monociti, ćelije prirodne ubice (NK) i različiti medijatori zapaljenja: C-reaktivni protein, fibrinogen, interleukin-1 (IL-1), interleukin-6 (IL-6), faktor tumorske nekroze alfa (TNF- $\alpha)(7)$.

Tradicionalni kardiovaskularni faktori rizika, uključujući muški pol, pozitivnu porodičnu anamnezu, starost, dislipidemiju, arterijsku hipertenziju, šećernu bolest, gojaznost, pušenje, ne objašnjavaju u potpunosti povećanu učestalost KVB kod pacijenata sa RA. Nastanak ateroskleroze, koja se obično i razvija tokom dužeg vremenskog perioda, asimptomatski, povezan je s brojnim faktorima rizika, uključujući mnoge nezdrave životne navike, kao i genetske faktore (9).

Pored uloge u nastanku ateroskleroze, pretpostavlja se da oksidativni stres ima značajnu ulogu i u patogenezi tkivnih oštećenja kod RA.

Oštećenje endotela kod pacijenata sa RA dovodi do endotelne disfunkcije koja se manifestuje nemogućnošću endotela da adekvatno reaguje na vazodilatatorne stimuluse. Endotelna disfunkcija se dokazuje ili ultrazvučnim određivanjem vazodilatacije posredovane protokom krvi (engl. flow mediated vasodilatation, FMV) ili određivanjem nivoa asimetričnog dimetilarginina (ADMA) u plazmi (4).

Smirivanje upalnog procesa kod RA primenom bioloških lekova i/ili efikasnih sistemskih lekova povezano je sa smanjenjem rizika od razvoja kardiovaskularnih oštećenja.

\section{Sjegrenov sindrom}

Sjegrenov sindrom (SjS) predstavlja hroničnu sistemsku autoimunu bolest koja primarno zahvata egzokrine žlezde. Promene su najizraženije u suznim i pljuvačnim žlezdama, pa su suvoća očiju (kseroftalmija) i usta (kserostomija) osnovni klinički simptomi bolesti. Međutim, mogu da budu zahvaćene i druge egzokrine žlezde (respiratorne, gastrointestinalne, genitourinarne i kožne). Bez obzira na činjenicu da u kliničkoj slici kod ovih pacijenata prevladavaju promene u žlezdama, kod nekih od njih zahvaćeni su i koštano-mišićni sistem, koža pluća, bubrezi, jetra i periferni nervni sistem (10).

Sjegrenov sindrom je posebno važan u kliničkoj praksi jer bolesnici sa SjS imaju oko 4 puta veći rizik za nastanak KVB u odnosu na kontrole. Oboljenje se može javiti u bilo kom životnom dobu, ali se najčešće javlja u petoj i šestoj deceniji života i to kod žena, pri čemu se učestalost povećava sa starošću. Bolest je znatno češća kod žena nego kod muškaraca (9:1). U zemljama Zapadne Evrope SjS je druga po prevalenciji zapaljenjska reumatska bolest (10).

Procenjuje se da je prevalencija SjS između 0,05\% i
$4,8 \%$ svetske populacije. Prilagođeni standardizovani odnos smrtnosti kod pacijenata sa SjS iznosi 1,38, bez značajnog povećanja smrtnosti od svih uzroka u poređenju sa opštom populacijom. Što se tiče uzroka smrtnosti, KVB su zabeležene kao vodeći uzroci smrti. Poznato je da, u poređenju sa opštom populacijom, pacijenti sa SjS imaju povećan rizik od maligniteta, posebno nehočkinskog limfoma i kardiovaskularnih oboljenja, a taj rizik može biti i 13,78 puta veći u odnosu na opštu populaciju (11).

Među svim KVB, ishemijska bolest srca je vodeći uzrok smrtnosti u celom svetu. U 2012. godini su kardiovaskularna oboljenja i moždani udar predstavljali $42,3 \%$, odnosno $38,3 \%$ svih smrtnih slučajeva, a oba ova oboljenja potiču od ateroskleroze. U razvoj ateroskleroze su uključeni mnogi faktori rizika, poput hipertenzije, hiperlipidemije, dijabetesa, pušenja itd. Ovi tradicionalni faktori rizika, međutim, ne objašnjavaju u potpunosti verovatnoću za razvoj bolesti srca jer su mnoga istraživanja identifikovala ulogu inflamacije i raznih autoimunih fenomena u njihovoj pojavi. Autoimune bolesti će verovatno biti jedan nezavisni faktor rizika za nastanak ateroskleroze usled osnovne hronične upale (11).

\section{Sistemski eritemski lupus}

Sistemski eritemski lupus (SLE) je sistemsko autoimuno oboljenje kod koga su oštećenja posredovana autoantitelima i imunim kompleksima. U Sjedinjenim Američkim Državama (SAD) učestalost SLE je 15 - 50 na 100.000 stanovnika $(8,11)$.

Sistemski eritemski lupus nastaje kao rezultat delovanja genetskih faktora i faktora spoljašnje sredine. Patološki imuni odgovor kod SLE podrazumeva poliklonsku i antigen specifičnu hiperaktivnost T- i B-limfocita i nefunkcionalnu regulaciju date hiperaktivnosti. Imuni kompleksi kod pacijenata sa SLE ne eliminišu se adekvatno i deponuju se u zidovima krvnih sudovima sa razvojem vaskulitisa. Značajni faktori u ovoj bolesti su UVA i UVB zraci jer čak 70\% pacijenata ima fotosenzitivnost. Studije koje su ispitivale virusnu infekciju kao mogući inicijalni događaj za nastanak ovog oboljenja nisu dale konkretne rezutate. Neki lekovi (hidralazin, prokainamid i dr.), međutim, mogu dovesti do tzv. sindroma nalik lupusu, ali se on ipak jasno razlikuje od SLE.

Kao što je već napred navedeno, kod bolesnika sa SLE, koji bolest imaju duže od 5 godina najčešći uzrok smrti su KVB (62).

Ishemijska bolest srca se sreće kod mladih pacijenata sa dijagnozom SLE, a može biti rezultat nekoliko patofizioloških mehanizama, uključujući aterosklerozu, artritis, trombozu i abnormalni koronarni tok.

Upečatljiva klinička karakteristika bolesnika sa SLE koji imaju infarkt miokarda je njihova starosna dob. Povećan rizik od infarkta miokarda je naročito prisutan u mlađoj populaciji. Zabeleženo je da je mortalitet zbog infarkta miokarda 2 - 3 češći kod pacijenata sa SLE u odnosu na kontrolnu grupu ispitanika komparabilnih po uzrastu i polu (10). 
Vasilev V. et al. Dijagnostika kardiovaskularnih bolesti kod bolesnika sa reumatoidnim artritisom, primarnim Sjegrenovim sindromom, sistemskom sklerozom i sistemskim eritemskim lupusom. MedPodml 2021, 72(4):1-7

Uticaj IBS na morbiditet i smrtnost kod pacijenata sa utvrđenim SEL ima sve veći klinički značaj tokom njihovog dugoročnog lečenja. Sistemski eritemski lupus karakteriše hronična upala, a zapaljenje je značajna karakteristika aterosklerotičnih lezija. Primećeno je da je prevalencija klinički manifestne IBS u raznim studijama između $8 \%$ i $16 \%$. Klinička epidemiološka zapažanja snažno ukazuju na to da, zajedno sa klasičnim konvencionalnim faktorima rizika, postoje i drugi mehanizmi (nekonvencionalni/faktori specifični za bolest) koji dovode do ubrzane ateroskleroze. Sistemski eritemski lupus se sada smatra nezavisnim faktorom rizika za razvoj ateroskleroze (12).

\section{Sistemska skleroza}

Sistemska skleroza (SSc) predstavlja oboljenje nepoznate etiologije koje zahvata mnoge organe i ima vrlo raznoliku kliničku manifestaciju. Glavne karakteristike su izrazito pojačana fibroza kože i unutrašnjih organa i vaskulopatija usled nagomilavanja komponenti ekstracelularnog matriksa u različitim tkivima i organima. Radi se o izuzetno retkoj bolesti koja se obično javlja u 4. i 5. deceniji života, pri čemu incidencija oboljenja dosta zavisi od pola i rase. Oboljenje se javlja 4-6 puta češće kod osoba ženskog pola u odnosu na muški pol. Različite studije su pokazale da je incidencija ovog oboljenja između 0,6 - 19 na 100.000 stanovnika, pri čemu se u poslednje vreme zapaža trend porasta učestalosti (13). Najveća incidencija i prevalencija opisane su u SAD i Australiji, a najniža u zemljama severne Evrope i Azije. Podaci iz literature takođe pokazuju da učestalost ovog oboljenja dosta varira u samoj Evropi i to tako što je oboljenje znatno češće na jugu Evrope u odnosu na sever. Novije studije, međutim, pokazuju relativno visoku prevalenciju SSc od 23,5/100.000 u Švedskoj. Na osnovu rezultata različitih studija poznato da postoje velike razlike u učestalosti ovog oboljenja između različitih regiona, ali još uvek nije jasno da li je ta razlika uzrokovana delovanjem različitih spoljašnjih faktora i/ili je posledica genetskih faktora (11).

Sistemska skleroza predstavlja oboljenje sa povećanim mortalitetom, pri čemu stopa preživljavanja ovih bolesnika dosta zavisi od težine sklerodermije i oštećenja vitalnih organa. Mortalitet kod ovog oboljenja iznosi 30 - 80\%. Poremećaj rada bubrega sa pojavom „renalne krize“ ranije je bio glavni uzrok smrti ovih bolesnika, dok je u poslednje vreme najčešći uzrok intersticijalna bolest pluća. Povećana stopa smrtnosti je povezana sa faktorima koji se odnose na pol, difuzni oblik bolesti, životna dob preko 50 godina u trenutku postavljanja dijagnoze i prisustvo anti-Scl 70 antitela (2).

Oboljenje srca i kardiovaskularnog sistema se sreće kod 15 - 35\% bolesnika sa SSc, ali se supkliničko oboljenje nalazi kod značajno većeg broja pacijenata. Nalaz obdukcije ukazuje da je ovo obljenje prisutno kod $80 \%$ slučajeva SSc pacijenata. Zastupljenost KVB varira između studija, u zavisnosti od metoda koji se koriste za procenu. Mogu da budu zahvaćene sve srčane strukture: endokard, miokard, perikard, zalisci, koronarne arterije, sprovodni i autonomni nervni sistem, koje mogu dovesti do srčanog zatajenja. Srčana oboljenja kao najčešći komorbiditeti sreću se kod oba oblika bolesti, ali su dominatniji u difuznom obliku SSc (2).

Jedno od glavnih obeležja SSc jesu i promene na krvnim sudovima, ali mehanizmi nastanka ovih promena još uvek su nedovoljno poznati. Oštećenje krvnih sudova obuhvata promene koje zahvataju sva tri sloja krvnog suda i karakteriše se fibrotičnom intimalnom hipreplazijom. Proces fibroze obično počinje u intimi mediji zidova krvnih sudova srednje veličine, pa se zatim širi na intimu i adventiciju, remeteći elasticitet krvnog suda. S vremenom dolazi do zadebljanja intime i okluzije krvnog suda (13). Početni događaj koji dovodi do oštećenja krvnih sudova je, pre svega, oštećenje endotelnih ćelija dejstvom različitih faktora i dosta je sličan početnom stadijumu fibroze. Primarno oštećenje miokarda podrazumeva vaskularne lezije i depozite fibroze, što može uticati na koronarnu mikrocirkulaciju i funkciju miokarda. Na osnovu ranijih rezultata ispitivanja, najznačajniji patohistološki nalaz u miokardu obolelih predstavljen je fibrozom pojedinih delova miokarda u vidu malih ognjišta izmenjenog mišićnog tkiva (13).

\section{Kardiovaskularna dijagnostika kao stratifikacija rizika kod pacijenata sa reumatskim autoimunim oboljenjima}

Širom sveta raste broj ljudi koji boluju od neke reumatske autoimune bolesti i smatra se da će taj broj dostići i do $1 \%$ svetske populacije do 2025. godine (14). Ovi pacijenti imaju 2-4 puta veći rizik za nastanak KVB. Bitno je istaći da je mortalitet usled KVB najveći kod pacijenata sa RA, ali je povećan i kod ostale tri ispitivane grupe bolesnika. Poznato je da je kod ovih bolesnika učestalost IBS znatno veća u odnosu na opštu populaciju i postojeći skorovi i tablice za procenu kardiovaskularnog rizika nisu dovoljni za ovu grupu bolesnika. Dodatni problem predstavlja i diskrepanca KVS simptoma i oštećenja KVS kod ovih bolesnika (14).

Zbog svega navedenog, potrebna je rana dijagnoza KVB kod ovih bolesnika. Američka asocijacija za autoimuna reumatska oboljenja objavila je smernice za dijagnozu KVB kod ovih bolesnika koje, pre svega, uključuju upotrebu neke od imidžing metoda, kao što je jednofotonska emisiona kompjuterizovana tomografija (SPECT) miokardna ili stresna ehokardiografija (SEHO) (15).

„Zlatni standard“ detekcije koronarne bolesti je invazivna koronarna angiografija, ali je invazivna i skupa, a povezana je i sa pojavom različitih komplikacija. Zato se danas sve više koriste neinvazivni testovi koji se mogu podeliti na funkcionalne (indirektno detektuju hemodinamske posledice ishemije) i anatomske (detektuju aterosklerozu i omogućavaju vizualizaciju koronarnih arterija).

\section{Funkcionalne tehnike}

Osnova ovih tehnika se zasniva na indirektnom prepoznavanju znakova koronarne bolesti koji nastaju kao posledica hemodinamskih poremećaja izazvanih ishemijom. 
Vasilev V. et al. Dijagnostika kardiovaskularnih bolesti kod bolesnika sa reumatoidnim artritisom, primarnim Sjegrenovim sindromom, sistemskom sklerozom i sistemskim eritemskim lupusom. MedPodml 2021, 72(4):1-7

U toku ishemijske kaskade u početku se javljaju poremećaji mikrocirkulacije i perfuzije, zatim ehokardiografski znaci u smislu poremećaja segmentne kinetike leve komore, nakon čega slede elektrokardiografski (EKG) znaci ishemije i tek na kraju bol u grudima. Zbog ove činjenice ergometrijski test ima slabu senzitivnost za otkrivanje koronarne bolesti, kako kod zdravih bolesnika, tako i kod bolesnika sa reumatskim oboljenjima, zbog čega se ne preporučuje za otkrivanje koronarne bolesti kod ovih bolesnika (119).

Od funkcionalnih tehnika za procenu koronarne bolesti mogu se koristiti dijagnostičke metode koje procenjuju perfuziju miokarda, kao što su nuklearne tehnike: pozitronska emisiona tomografija (PET) ili emisiona tomografija pojedinačnim fotonima, procena perfuzije miokarda metodom prvog prolaza na magnetnoj rezonanci (MR) srca, kao i miokardna kontrastna ehokardiografija ili imidžing tehinke koje procenjuju segmentnu kinetiku leve komore: stresna ehokardiografija, stress cardiac MR ili SPECT snimanje na ishemiju.

Kod svih ovih tehnika ishemija se otkriva poređenjem nalaza tokom stresa ili odmah u toku oporavka i nalaza u miru, bilo da se radi o otkrivanju novog defekta perfuzije miokarda tokom stresa ili pogoršanja postojećih poremećaja segmentne kinetike tokom stresa. Stres se može postići fizičkim opterećenjem, kao što su vožnja ergobicikla ili hodanje po pokretnoj traci ili, kod bolesnika koji nisu u stanju da to izvedu, upotrebom farmakoloških agensa (16).

\section{Anatomske tehnike}

Korišćenjem anatomskih testova obezbeđuje se direktna vizuelizacija koronarnih arterija. Postoji nekoliko različitih metoda, uključujući $\mathrm{MR}$, multidetektorsku kompjutersku tomografiju (MSCT) i emiosionu kompjutersku tomografiju (EBCT). Imajući u vidu da su koronarne arterije malog prečnika i da se kreću u skladu sa srčanim ciklusom, njihovo detaljno prikazivanje, kao i procena mogu predstavljati veliki izazov kod svih navedenih tehnika. I pored svojih nedostataka, ove tehnike, pored toga što su nenvazivne prirode, omogućavaju nam i procenu morfologije aterosklerotičnog plaka (16).

\section{Dijagnostička tačnost}

\section{Funkcionalne tehnike}

U praksi je najčešće korišćena metoda za procenu perfuzije miokarda SEPCT. Kod ove tehnike prvo se vrši procena perfuzije u miru, a zatim se ocenjuje perfuzija u naporu. Dobijeni defekti u perfuziji mogu biti reverzibilni, kada ukazuju na ishemiju miokarda ili ireverzibilni, kada ukazuju na nevijabilno tkivo miokarda, odnosno ožiljak.

Senzitivnost i specifičnost SPECT-a za otkrivanje koronarne bolesti, u poređenju sa invazivnom koronarnom angiografijom, iznose $86 \%$, odnosno $74 \%$.

$\mathrm{S}$ druge strane, $\mathrm{SEHO}$ je najčešće korišćena metoda za procenu segmentne kinetike leve komore. Ovaj test može da se izvodi putem fizičkog opterećenja ili upotrebom farmakoloških agensa. Poređenjem koronarne angiografije sa senzitivnošću i specifičnošću SEHO testa za detekciju koronarne bolesti uočavamo vrlo slične nalaze (84 \% i 82 \%) (16-18).

\section{Miokardna kontrastna ehokardiografija i kontrasna magnetna rezonanca}

Sa razvojem novih kontrasnih sredstava ove tehnike se danas sve više koriste jer nam, pored detekcije stenoza na epikardijalnim koronarnim krvnim sudovima, daju i značajne informacije o mikrocirkulaciji. Slično kao i kod SPECT-a, perfuzioni defekti u miru predstavljaju ožiljak, dok revezibilni defekti u naporu ukazuju na koronarnu bolest. Senzitivnost i specifičnost ove metode iznose 74\%, odnosno $85 \%$, u poređenju sa invazivnom angiografijom.

Kontrastna magnetna rezonanca se zasniva na intravenskom davanju kontrastnog sredstva tokom snimanja, pri čemu se defekti u perfuziji prikazuju kao zone sa niskim intenzitetom signala. Velika prednost ove metode je to što se, usled velike prostorne rezolucije, mogu razlikovati transmuralni, subepikardni i subendokardni defekti u perfuziji, što ima veliki dijagnostički značaj. Senzitivnost i specifičnost ove metode iznose $74 \%$, odnosno $85 \%$ u poređenju sa koronarnom angiografijom (19).

\section{Anatomske tehnike}

\section{Kalcijumski skor koronarnih arterija}

Dve osnovne tehnike za vizuelizaciju koronarnih arterija, kao i za detekciju i kvantifikaciju depozita kalcijuma u zidovima koronarnih krvnih sudova su multislajsna kompjuterizovana tomografija (MSCT) i emisiona kompjuterizovana tomografija. pri čemu je emisiona tomografija dostupnija i ima znatno nižu dozu zračenja u odnosu na MSCT. Za kvantifikaciju depozita kalcijuma u zidovima koronarnih krvnih sudova razvijen je Agatston skor, koji jako dobro korelira sa nalazom koronarne bolesti. Vrednosti skora manje od 10 predstavljaju nesignifikantni kalcijum, vrednosti od 11 do 100 malo nakupljanje kalcijuma, 101 - 400 srednje nakupljanje kalcijuma, 401 - 1000 veliku količinu kalcijumskih depozita, dok vrednost veća od 1000 predstavlja ekstenzivno nakupljanje kalcijuma. Bez obzira na činjenicu da je veći Agatston skor veoma blisko povezan sa uznapredovalom aterosklerozom, skor se ne može koristiti za detekciju koronarne bolesti, naročito kod starijih bolesnika, ali može da nam pruži dosta informacija o prognozi i daljoj stratifikaciji rizika (20).

\section{Neinvazivna angiografija magnetnom rezonancom}

Angiografija magnetnom rezonancom omogućava neinvazivnu vizuelizaciju koronarnih arterija. Međutim, uprkos početnim rezultatima studija koje su pokazale veliku senzitivnost i specifičnost ove metode za otkrivanje koronarne bolesti, ova metoda se danas ređe koristi zbog manje dostupnosti i činjenice da su druge metode bolje. Sa daljim razvojem tehnologije ova metoda će sigurno imati veći značaj u budućnosti (21). 
Vasilev V. et al. Dijagnostika kardiovaskularnih bolesti kod bolesnika sa reumatoidnim artritisom, primarnim Sjegrenovim sindromom, sistemskom sklerozom i sistemskim eritemskim lupusom. MedPodml 2021, 72(4):1-7

Neinvazivna multislajsna kompjuterizovana tomografija

Danas je MSCT metoda izbora za neinvazivnu vizuelizaciju koronarnih arterija, naročito imajući u vidu da je danas 64-slajsni (detektorski) skener klinički standard. Senzitivnost i specifičnost ove metode za otkrivanje koronarne bolesti iznose 91\%, odnosno 96\%, pri čemu procenat neinterpretabilnih segmenata iznosi $0-12 \%$. Sama metoda je laka za izvođenje, dostupna, ali ipak ima veliku dozu zračenja i izvesna tehnička ograničenja, kao na primer da prostorna rezolucija ove metode dosta zavisi od srčane frekvencije (ukoliko je veća od 80/min, snimak može biti neinterpretabilan) $(21,22)$.

Neinvazivna angiografija putem emisione kompjuterske tomografije

Ova metoda ima dosta veliku prostornu i vremensku rezoluciju, što omogućava dosta jasno i detaljno neinvazivno prikazivanje koronarnih arterija, Njene senzitivnost i specifičnost su nešto manje u odnosu na MSCT i iznose $87 \%$, odnosno $91 \%$, ali je kod ove metode takođe i manja doza zračenja (22).

\section{Detekcija koronarne bolesti}

Razlike između funkcionalne i anatomske dijagonostike

„Zlatni standard” za otkrivanje koronarne bolesti je invazivna koronarna angiografija, koja definiše koronarnu bolest kada postoji suženje lumena nekog od epikardijalnih krvnih sudova veće od 50\%. U brojnim studijama je pokazano da anatomski definisana koronarna bolest, odnosno stenoza veća od $50 \%$ ne dovodi uvek do ishemije na funkcionalnim testovima. U ranijim studijama se pokazalo da skoro 50\% intermedijarnih stenoza (50-70\% suženja lumena) ne dovode do ishemije na SPECT-u.

I CT tehnike mogu definisati stenozu manju od 50\% kada je na angiografiji stenoza veća od 50\%.

\section{Stresna ehokardiografija}

U literaturi postoji veliki broj podataka o upotrebi stresne ehokardiografije (SEHO) za određivanje prognoze ishoda bolesti u opštoj populaciji. Slično je i sa podacima koji se odnose na primenu nuklearnih tehnika. Na osnovu podataka dobijenih primenom stresne ehokardiografije mogu se razlikovati pacijenti sa niskim, intermedijarnim i visokim rizikom. Ovaj test ima odličnu negativnu prediktivnu vrednost, tj. bolesnici sa normalnim nalazom SEHO testa imaju odličnu prognozu. U metaanalizi koja je obuhvatila 13 studija sa 32.739 pacijenata, učestalost smrti i/ ili infarkta miokarda kod bolesnika sa negativnom SEHO testom bila je dosta mala $(1,2 \%)$, dok je kod bolesnika sa pozitivnim SEHO testom ta učestalost bila dosta visoka (7\%). Ova studija je pokazala veoma značajnu ulogu SEHO testa u stratifikaciji rizika i prognozi $(18,23)$.
Kalcijumski skor koronarnih arterija

Kalcijumski skor ima dobru prognostičku vrednost, ali malu vrednost $\mathrm{u}$ otkrivanju koronarne bolesti. U studiji koja je uključila 10.000 asimptomatskih ispitanika, kalcijumski skor je određivan pomoću EMBT i ti bolesnici su bili praćeni 5 godina. Pokazano je da bolesnici bez ili sa niskom skorom imaju odlično preživljavanje (99\%). Nasuprot ovoj grupi, kod bolesnika sa veoma visokim kalcijumskim skorom (>1.000) petogodišnji mortalitet bio je 12,3\%, tako da kalcijumski skor ima dobru ulogu u stratifikaciji rizika za razvoj koronarnih događaja. Čak i u kombinaciji sa tradicionalnim faktorima rizika za KVB, kalcijumski skor ima značajnu prediktivnu vrednost. Pokazano je da bolesnici sa srednjim rizikom i niskim kalcijumskim skorom imaju mortalitet od 3,9\%, a bolesnici sa srednjim rizikom i visokim kalcijumskim skorom od čak 9\% (20).

\section{Potreba za skriningom asimptomatskih}

pacijenata sa autoimunim reumatskim bolestima

Bolesnici sa reumatskim oboljenjima su, zbog oštećenja koronarnih krvnih sudova, u znatno većem riziku za pojavu kardiovaskularnih događaja u odnosu na opštu populaciju. Kod njih jako često postoji ishemija miokarda, bez ikakvih kliničkih simptoma.

Udruženja koja se bave ispitivanjem autoimunih reumatskih bolesti konsenzusom preporučuju da se skrining IBS kod asimptomatskih bolesnika kod kojih postoje EKG promene u miru vrši SEHO testom, ali ne i kod bolesnika sa cerebralnom i perifernom vaskularnom bolešću koji imaju 2 ili više tradicionalna faktora rizika za IBS. Međutim, pokazano je i da bolesnici sa manje od 2 tradicionalna faktora rizika za IBS mogu imati pozitivan SPECT ili SEHO test, što ukazuje da tradicionalni faktori rizika, kao i skorovi bazirani na njima, nisu adekvatni da procene rizik za razvoj KVB kod ovih bolesnika $(7,24)$.

Kako se poslednjih decenija znatno povećava broj bolesnika sa reumatskim oboljenjima, neophodno je napraviti adekvatan izbor dijagnostičkog algoritma i stratifikaciju rizika za nastanak KVB kod ovih bolesnika. Funkcionalne tehnike su lako dostupne i neinvazivne i mogu da pokažu postojanje ishemije miokarda kod ovih bolesnika. Poslednjih godina se, međutim, sve više koriste anatomske tehnike (EBCT i MSCT) jer one omogućavaju vizuelizaciju koronarnih arterija, detektovanje funkcionalno neznačajnih aterosklerotičnih suženja i omogućavaju da se proceni morfologija samog plaka, ali ove metode nam ne daju informaciju o postojanju ishemije miokarda. S obzirom na veliku učestalost ishemije miokarda bez ikakvih kliničkih simptoma (nema ishemija), neophodan nam je adekvatan skrining ovih bolesnika. Na nesreću, postoji mali broj studija koje su se bavile ispitivanjem poboljšane prognoze bazirane na skriningu. Zbog toga je jako bitno da se sprovedu velike prospektivne studije u smislu ispitivanja prediktivnih markera pojave i razvoja koronarnih oboljenja kod pacijenata sa autoimunim reumatoidnim oboljenjima (16). 
Vasilev V. et al. Dijagnostika kardiovaskularnih bolesti kod bolesnika sa reumatoidnim artritisom, primarnim Sjegrenovim sindromom, sistemskom sklerozom i sistemskim eritemskim lupusom. MedPodml 2021, 72(4):1-7

\section{Zaključak}

Hronična reumatološka oboljenja, a naročito RA, povezana su sa povećanim mortalitetom, uglavnom zbog kardiovaskularnih komplikacija, koje su po nekim istraživanjima odgovorna za čak $50 \%$ preranih smrti ovih bolesnika. Najčešća kardiovaskularna komplikacija kod ovih bolesnika je koronarna bolest, mada su moguće i druge kardiovaskularne komplikacije, kao što su valvularna bolest srca, perikarditis, endokarditis, aritmije i reumatoidni čvorovi u srcu, ali su one ipak dosta ređe u poređenju sa KB. Tradicionalni faktori rizika, kao što su hipertenzija, pušenje, dislipidemija i gojaznost, koji značajno doprinose endotelnoj disfunkciji i nastanku ateroskleroze kod ovih bolesnika, ne mogu u potpunosti objasniti veću učestalost KB kod ove populacije. Ova grupa oboljenja se karakteriše stalno visokim stepenom inflamacije, a danas je poznato da upravo ona dovodi do endotelne disfunkcije i ubrzane ateroskleroze kod ovih bolesnika. Povećanje brojnosti svetske populacije koja boluje od reumatoidnih autoimunih oboljenja u svetu i povećani morbiditet i mortalitet ovih bolesnika iziskuju razvoj adekvatne dijagnostičke strategije za detekciju koronarne bolesti i stratifikaciju rizika.

\section{Literatura}

1. Meune C, Touzé E, Trinquart L, Allanore Y. High risk of clinical cardiovascular events in rheumatoid arthritis: Levels of associations of myocardial infarction and stroke through a systematic review and meta-analysis. Arch Cardiovasc Dis. 2010; 103(4):253-61.

2. Nie LY, Wang XD, Zhang T, Xue J. Cardiac complications in systemic sclerosis: early diagnosis and treatment. Chin Med J (Engl). 2019; 132(23):2865-71.

3. Kremers HM, Crowson CS, Therneau TM, Roger VL, Gabriel SE. High ten-year risk of cardiovascular disease in newly diagnosed rheumatoid arthritis patients: a population-based cohort study. Arthritis Rheum. 2008; 58(8):2268-74.

4. Stevens RJ, Douglas KM, Saratzis AN, Kitas GD. Inflammation and atherosclerosis in rheumatoid arthritis. Expert Rev Mol Med. 2005; 7(7):1-24.

5. Zanatta E, Colombo C, D'Amico G, d'Humières T, Dal Lin C, Tona F. Inflammation and Coronary Microvascular Dysfunction in Autoimmune Rheumatic Diseases. Int J Mol Sci. 2019; 20(22).

6. Frantz C, Auffray C, Avouac J, Allanore Y. Regulatory T Cells in Systemic Sclerosis. Front Immunol. 2018; 9:2356.

7. Kitas G, Banks MJ, Bacon PA. Cardiac involvement in rheumatoid disease. Clin Med (Lond). 2001; 1(1):18-21.

8. Fortuna G, Brennan MT. Systemic lupus erythematosus: epidemiology, pathophysiology, manifestations, and management. Dent Clin North Am. 2013; 57(4):631-55.

9. Dessein PH, Joffe BI, Stanwix AE. Inflammation, insulin resistance, and aberrant lipid metabolism as cardiovascular risk factors in rheumatoid arthritis. J Rheumatol. 2003; 30(7):1403-5.

10. Vivino FB. Sjogren's syndrome: Clinical aspects. Clin Immunol. 2017; 182:48-54.

11. Symmons DP, Gabriel SE. Epidemiology of CVD in rheumatic disease, with a focus on RA and SLE. Nat Rev Rheumatol. 2011;7(7):399-408.

12. Fava A, Petri M. Systemic lupus erythematosus: Diagnosis and clinical management. J Autoimmun. 2019; 96:1-13.

13. Matucci-Cerinic M, Kahaleh B, Wigley FM. Review: evidence that systemic sclerosis is a vascular disease. Arthritis Rheum. 2013; 65(8):1953-62.
14. Alenghat FJ. The Prevalence of Atherosclerosis in Those with Inflammatory Connective Tissue Disease by Race, Age, and Traditional Risk Factors. Sci Rep. 2016; 6:20303.

15. Zegkos T, Kitas G, Dimitroulas T. Cardiovascular risk in rheumatoid arthritis: assessment, management and next steps. Ther Adv Musculoskelet Dis. 2016; 8(3):86-101.

16. Heo R, Nakazato R, Kalra D, Min JK. Noninvasive imaging in coronary artery disease. Semin Nucl Med. 2014; 44(5):398-409.

17. Ramjattan NA, Lala V, Kousa O, Makaryus AN. Coronary CT Angiography. StatPearls. Treasure Island (FL): StatPearls Publishing Copyright ( 2021, StatPearls Publishing LLC. 2021.

18. Saghir MK, Attenhofer Jost C, Warrington KJ, Cha SS, Pellikka PA. Exercise echocardiography in rheumatoid arthritis: a case-control study. J Am Soc Echocardiogr. 2009; 22(11):1228-31.

19. Gawrysiak W, Skrypnik K, Suliburska J, Skrypnik D, Bogdański P. Cardiac complications in rheumatoid arthritis, systemic lupus erythematosus and systemic sclerosis. Przegl Lek. 2017; 74(4):179-82.

20. Hegde M, Rajendran R. SYNTAX Score in Patients with High Computed Tomography Coronary Calcium Score. J Clin Imaging Sci. 2016; 6:46.

21. Achenbach S. Computed tomography coronary angiography. J Am Coll Cardiol. 2006; 48(10):1919-28.

22. Dendukuri N, Chiu K, Brophy JM. Validity of electron beam computed tomography for coronary artery disease: asystematic review and meta-analysis. BMC Med. 2007; 5:35.

23. Gu MM, Wang XP, Cheng QY, Zhao YL, Zhang TP, Li BZ, et al. A Meta-Analysis of Cardiovascular Events in Systemic Lupus Erythematosus. Immunol Invest. 2019; 48(5):505-20.

24. Aviña-Zubieta JA, Choi HK, Sadatsafavi M, Etminan M, Esdaile JM, Lacaille D. Risk of cardiovascular mortality in patients with rheumatoid arthritis: a meta-analysis of observational studies. Arthritis Rheum. 2008; 59(12):1690-7. 